\title{
Economics of transport and sustainable development: problems of high education in Russia
}

\author{
Alina Kankovskaya ${ }^{1 *}$, Olga Kalinina ${ }^{1}$ and $\operatorname{Igor}$ Ilin $^{1}$ \\ ${ }^{1}$ Peter the Great St. Petersburg Polytechnic University, Polytechnicheskaya, 29, St. Petersburg \\ 195251, Russia
}

\begin{abstract}
Transport is one of the most important spheres in the sustainable development of countries and regions. Therefore, the article analyses the extension of the concept of sustainable development in Russian higher education in transport engineering and economics. We analysed the higher education standards and educational programs of universities, identified problems in the implementation of the concept of sustainable development in Russian higher education in the field of transport engineering and suggested ways to address them.
\end{abstract}

\section{Introduction}

All over the world the sustainable development stands for the main possible global concept of social progress in the frames of the growing global human problems. It is essential to debate and to create a system of principles that pursue the sustainable development in all sectors of the economy. With the engineering and transport being at the forefront of sustainable development the term scientific approach to this problem should be considered. The sustainable development being the organizing principle for meeting human development goals without destabilizing the natural system stability as a main idea should be taken into account in the sphere of engineering and transport education.

The first definition of sustainable development appeared in the so-called Brundtland Report [1] named in recognition of former Norwegian Prime Minister Gro Harlem Brundtland appointed at the Chairperson of the World Commission on Environment and Development (WCED) by United Nations Secretary in December 1983. In our opinion, the Brundtland's definition sufficiently describes the goal and objectives of education for sustainable development. The matter is that the need for activity in the field of environmental education by itself was recognized a long time ago, however the concept of "education for sustainable development" seems to be much more broader and actual. The main objectives of it were formulated in Resolution 57/254 of the General Assembly of the United Nations (2002) [2], which established that education is an indispensable element for achieving sustainable development. The United Nations Decade of Education for Sustainable Development (2005-2014) has ended and the next stage is defined by

\footnotetext{
* Corresponding author: kankovskaya ar@spbstu.ru
} 
Transforming our World: The 2030 Agenda for Sustainable Development, which in goal 4.7 postulates that by 2030 it is necessary to ensure that all learners, “... acquire knowledge and skills needed to promote sustainable development, including among others through education for sustainable development and sustainable lifestyles, human rights, gender equality, promotion of a culture of peace and non-violence, global citizenship, and appreciation of cultural diversity and of culture's contribution to sustainable development [3, p.19]. It is the considerable increase of the interpretation of the concept of education for sustainable development. But we can see a very narrow approach to the interpretation of the concept of sustainable development as an ecological problem in Russia.

The history of education for sustainable development in Russia is discussed in detail by Pavlova [4] and Zhevlakova [5]. We agree with them on key problems:

- the role of the government is extremely small;

- the narrow approach - programmes of environmental education, the teaching of natural sciences and different activities in the field of ecology are called "education for sustainable development";

- a lot of educational projects of all sizes have been realized in Russia, but they have had a local character, used small resources and therefore could not give a systemic effect.

Pavlova clearly defines the difference between environmental education, where environment is at the centre of concerns and environment is external to the person, and education for sustainable development, where human beings are at the centre of concerns, environment is extension of the person, the aim is to promote a new model of society and the focus is on provision of education, curriculum and learning [6, p.664].

Transport is taking an active initiative to develop sustainability practices in different countries, and we share the view [7,8] that there is a growing demand for transport professionals with sustainability skillsets and universities must provide this emerging need of national economy.

The achievement of sustainable development goals requires the mobilization of financial resources, the selection of projects and the resource allocation. Therefore, in our opinion, it is necessary to emphasize the economics aspects (and as a consequence, the economic education and training) in the field of transport.

Thus the goal of the paper is to identify problems in the implementation of the concept of sustainable development in Russian higher education in area of economics of transport and to formulate prospects for development.

The following tasks are to be done to achieve the goal:

- to examine existing federal state educational standards in area of transport and economics from the position of the concept of sustainability;

- to analyse programmes of higher education in terms of sustainable development;

- to formulate proposals for the development of higher education.

\section{Overview of Russian national educational standards and educational programmes: data and results}

Analysis of higher education in terms of sustainable development in Russia needs the following data sources. In the Russian Federation, the first level of the system of state regulation of education is the Federal Law on Education in Russian Federation (the newest version - No. 273-FZ - was adopted on 29th December 2012, came into force on 1st September 2013 and has a number of supplements) [9]. The second level is the system of Federal State Educational Standards, which sets out requirements for learning outcomes in education, including areas of professional activity, objects and types of professional activity and development of competences [10]. The third level is the universities' level, so it is necessary to examine universities' sites and various educational sites to identify admission 
quotas and the content of educational programmes. Our analysis of the system of Federal State Educational Standards shows a very narrow approach to the understanding of sustainable development.

The competence model in Federal State Educational Standards integrates three types of competence: general cultural, general professional and professional (instrumental). There are two types of Federal State Educational Standards - the first type includes instrumental competences, the second type postulates only general cultural and general professional competences and connects with a set of professional standards, which postulate instrumental competences. Curricula and content of courses are defined by this set of competences. So if any standard contains a competence, it will certainly be implemented in the learning process. If the standard does not include the competence, we can hope only for the professional standard and teacher with a global perspective. However, the concept of sustainable development is still unknown in Russian society, as confirmed by Salimova et al.'s research [11]. Understanding of the idea of sustainable development is at a very low level.

A content analysis was conducted of Federal State Educational Standards in four groups of educational programmes - Land Transport Engineering, Air Transport Engineering, Maritime Transport Engineering and Economics. Table 1 shows that sustainable development is not included within general and instrumental competencies in Transport Engineering and Economics. The wide concept of sustainable development as a global citizenship, global equality and human rights is reflected only in the aspect of cultural diversity, but this competence take place in each Federal State Educational Standards. There are several economic and management competencies in educational programmes only in Maritime Transport. There no economic competencies in educational programmes in Land and Air Transport. This is the first problem of education for sustainable development. The second problem is the lack of the concept of sustainability in Economics and Management.

Table 1. Competences in the sphere of sustainable development and economics in Federal State Educational Standards

\begin{tabular}{|l|c|c|c|c|}
\hline \multicolumn{1}{|c|}{ Professional area } & $\begin{array}{c}\text { Sustainable } \\
\text { development }\end{array}$ & $\begin{array}{c}\text { Cultural } \\
\text { diversity }\end{array}$ & Economics & Management \\
\hline Land Transport & - & + & + & - \\
\hline Air Transport & - & + & + & + \\
\hline Maritime Transport & - & + & + & + \\
\hline Economics & - & + & + & + \\
\hline
\end{tabular}

It is important to note that there are two popular educational programs in the sphere of economic education for the transport sector - Transport Enterprise Economy and Logistics. Both programs are included in the group "Economics". However, there is no an educational program as Transport Economics.

The next step of our investigation is the analyse of curricula and content of courses in the sphere of Transport and Transport Enterprise Economy. We analysed curricula and content of courses at some Russian universities: Land Transport (9 universities of the 61), Air Transport (5 of the 17), Maritime Transport (6 of the 27) and Transport Enterprise Economy in the same universities and found that: 
- the need for sustainable development, the concept of sustainability, its problems and prospects are not addressed in Transport and Transport Enterprise Economy;

- curricula and content of courses in Transport give sufficient attention to the formation and development of economic competencies, but does not include sustainable development economics.

- there are close links between economic and transport competencies in economic programs at the leading Russian universities, but these linkage is weak at some regional universities.

Thus, the gap between the Transport Enterprise Economy and Sustainable Development Economics has been revealed. It slows the development of transport engineering on the basis of sustainability, because economists working in this field are specialists in transport enterprise economics, but not in sustainable development economics.

\section{Problems and prospects}

Our investigation identified a set of problems:

- There is a very narrow approach for sustainable development in Russia - education for sustainable development is concentrated only in a few educational programmes: earth sciences, architecture, urban planning and civil engineering. Transport, which is very important for sustainable development of each country and the world, is not in this groupe of programs.

-The concept of sustainability is not popular in Russian society and Russian business.

- The lack of the concept of sustainability in Economics and Management.

The peculiarities of Russian society and statehood are the strong paternalism and the top-down approach. Therefore, we will formulate proposals at the level of government policy in the sphere of innovations, then in education as a subsystem of the national economy, and then in the competence model.

\subsection{Sustainable development in the system of NSI principles}

Since the concept of sustainable development is inseparable from innovative development, we consider it necessary to include the principle of sustainable development in the government policy of development of innovative economy. It is necessary to implement the principle of sustainable development into the system of principles of functioning and development of the national system of innovation (NSI). We agree with Hargroves and Smith [12] that sustainable development is a fundamentally different and modern approach to the development of NSI, proposing to arrange the principle of sustainable development above the set of national principles of functioning of the NSI.

This set varies considerably from country to country and in the same country at different stages of economic development. For Russia now it includes:

1. The principle of national security. The globalization and the decline of control over research activities on the part of the government are accompanied by an increasing influence by other countries and multinational corporations. The lack of effective mechanisms to control the transfer of scientific and technological developments in Russian practice leads to the loss of many breakthrough projects, especially complex and high-cost projects of sustainable development. Therefore systematic government activity on the orientation of scientific potential for the benefit of society is necessary.

2. The principle of congruency of the priorities of different levels. The multilevel nature of the NSI on the one hand, and the social and economic priorities of the country on the other, determine the need for hierarchical prioritization of the NSI. 
3. The principle of the elimination of bottlenecks. Deficiency of any resource on a micro or a macro level leads to losses and inefficient use of the existing scientific, technological and productive capacity. It takes on special significance for a transformed Russian NSI. The government needs to take measures to identify priorities and, in the context of sustainable development, it is necessary to use indicators of long-term socio-economic efficiency and to determine sustainability as a goal.

4. The principle of international scientific and technical cooperation. For each country it is necessary to participate in projects which are important in terms of co-evolution. More and more international projects in the field of transport are being implemented in Russia, so it is important to select and pursue them from the position of sustainability.

5. The principle of indicative management of scientific and technological development in implementation of the priorities sustainable development. Access to information on government priorities for business reduces uncertainty and makes possible a more efficient use of time and financial resources. We should emphasize the key role of government support due to the special nature of transport development and innovations.

The position of the principle of sustainable development as a top principle ensures the development of a national system of innovation, which is socio-economically effective in both the short and long term.

\subsection{Higher education and the concept of sustainability}

The problem of sustainable development is closely related to the development of the education system as a key element of the national system of innovation.

Research $[13,14]$ shows the most important problems of Russia's national innovation system and its weaknesses:

- The lack of economic incentives;

- Decision-makers are aiming at indicators of innovation instead of providing fertile ground for innovation;

- The development of an innovation environment is seen as a bureaucratic idea;

- Weak connections between elements of NSI;

- Underdeveloped market of innovation intermediaries.

At present, the institutions of the NSI and the state innovation policy ignore the existence of obsolete technologies and industries, as they are focused on finding and developing innovations in breakthrough industries. Quantitative indicators for them are more important than long-term socio-economic efficiency.

Therefore, urgent tasks of the national system of innovation and its sectoral subsystems (at including transport and urban development) are the transfer of production to a qualitatively new level and the transition to a knowledge economy and sustainable development. Thus, as substantiated in detail in [15], a partnership between business, government and universities on the basis of the triple helix, accompanied by the combination and interpenetration of their competences, appears. This facilitates an innovative breakthrough and provides stable sectoral competitiveness.

The higher education system is able to participate in all the subsystems of the NSI, realizing all functions within the NSI: education, research, innovation and stimulation, and this ability is unique. Universities are involved in the implementation of all phases of the innovation cycle, from preparation of highly qualified personnel to commercialization of research results. This ability is very important in innovative, technologically sophisticated industries such as transport engineering. Since the functions implemented by the higher education system in the NSI are closely interlinked, development of the higher education system on the basis of the concept of sustainable development should occur in all four functional areas and lead to a multiplier effect. 
Since the competences and curricula are determined by the demands of employers, the need for sustainable development education for specialists in the field of transport and transport engineering will be felt in the future. But, as a number of countries have already faced the problem of economic obstacles to sustainable development [15-17], we propose that the gap between the Transport Enterprise Economy and Sustainable Development Economics must be closed (Figure 1). It needs to use the existing organizational resources:

- introduction of principle of sustainable development in professional standards in transport engineering;

- inclusion of principles of sustainable development in the main part of educational programmes in Transport Engineering, Economics and Management as general cultural or general professional competences;

- an expanded role of transport economics in education programs and curricula;

- inter-disciplinary approach and connection of economic, human and engineering disciplines in educational programmes.

Thereby students will have a much higher level of development and awareness in their future careers based on the current trends of a sustainable development.

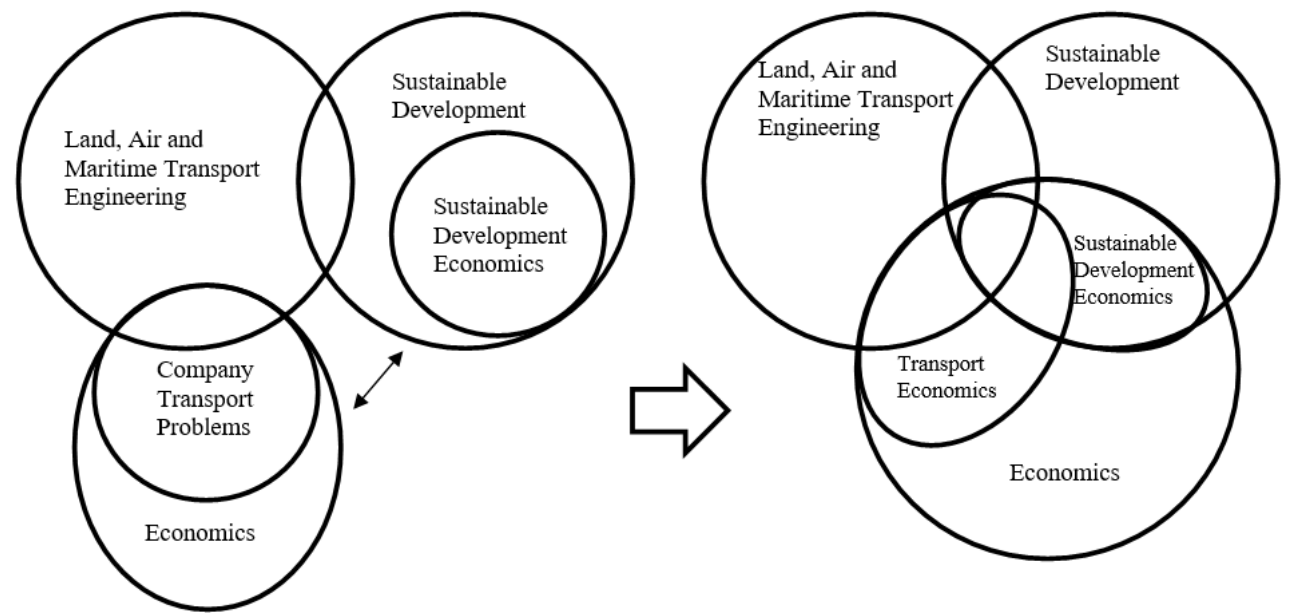

Fig. 1. Transformation of the competence model in the sphere of Transport Engineering and Economics

\section{Conclusion}

The paper covers the researching results of the problems in the implementation of the concept of sustainable development in Russian higher education in area of company transport problems and to formulate prospects for development. The conditions of the higher education system in Russia requires the study of the laws and regulations in the field of education and existing educational programmes. Our study of the Federal State Educational Standards of Higher Education, admission quotas, curricula and content of the courses in Transport Engineering and Economics reveals a gap between Transport Enterprise Economy and Sustainable Development Economics.

Since higher education is a very important subsystem of NSI, it is necessary to include the principle of sustainable development above the set of principles of government NSI' politics, in conjunction with the development of higher education on the basis of sustainability. 
As a result of our investigation, priorities are formulated for the development of a sustainable approach to Russian higher education, including incorporation of principles of sustainable development in the main part of educational programmes as general cultural or general professional competences and an inter-disciplinary approach in the realization of educational programmes. Identified problems suggest that it is advisable to devote time in further studies to examining the constraining factors in the development higher education for sustainable development.

\section{References}

1. World Comission on Environment and Development. Our common future. New York: Oxford University Press (1987).

2. UN Resolution 57/254. United Nations decade of education for sustainable development. Agenda item 87a. Document A/RES/57/254 Available at http://www.un-documents.net/a57r254.htm (accessed July 2018).

3. UN 2015 UN (United Nations). 2015. Transforming Our World: The 2030 Agenda for Sustainable Development. New York: United Nations. M. Pavlova, Technical and vocational education and training: issues, concerns and prospects; 10, 175-192 (2009).

4. M. Zhevlakova, Sustainable development in Russia. Russian-German environmental information bureau, 105-112 (2013)

5. M. Pavlova, Environmental Education Research, 19:5, 656-672 (2013), DOI: 10.1080/13504622.2012.736476.

6. R. Maclean, S. Jagannathan B. Panth, Technical and Vocational Education and Training: Issues, Concerns and Prospects. 27 (2017)

7. URL: http://www.cedefop.europa.eu/files/3057_en.pdf (accessed July 2018).

8. Federal Law on Education in Russian Federation (No. 273-FZ)

9. Federal State Educational Standards of Higher Education. Available at http://fgosvo.ru/fgosvo/92/91/4 (accessed July 2018).

10. T. Salimova, N. Guskova, E. Neretina Int J. Innovation and Sustainable Development, 9 (3/4) 246-261 (2015).

11. K. Hargroves, MN Smith, The natural advantage of nations: business opportunities, innovation and governance in the 21st century. (Routledge, Oxford, 2006)

12. V. Kaartemo, Russian innovation system in international comparison - the BRIC countries in focus. Electronic publications of Pan-European institute (2009);

13. URL: https://www.utu.fi/fi/yksikot/tse/yksikot/PEI/raportit-ja-tietopaketit /Documents/Kaartemo_Russian\%20innovation\%20system\%20in\%20international\%2 0comparison_2209\%20web.pdf (accessed July 2018).

14. T. Khvatova T. Proceedings of the 5th International Ph.D. School on Innovation and Economic Development, Globelics Academy, Tampere http://hdl.handle.net/1853/43538 (accessed December 2015).

15. M. Ranga, H. Etzkowitz, Industry and Higher Education, 27(4), 237-262 (2013)

16. B. Cavicchi, Energy Policy. 119, 585-599 (2018)

17. A. Enshassi, A. Ayash, S. Mohame, Int. Jour. of Building Pathology and Adaptation. 36, Issue 1, 15-40 (2018).

18. P. Miller, A.G. de Barros, KSCE Journal of Civil Engineering. Volume 20, Issue 3, 1 1076-1083 (2016) 